\title{
Zdzisław Majchrzyk
}

\section{Ekspertyzy psychologiczne w kontekście wizji osoby w ujęciu antropologii chrześcijańskiej}

Ius Matrimoniale 16 (22), 283-297

2011

Artykuł został opracowany do udostępnienia w internecie przez Muzeum Historii Polski w ramach prac podejmowanych na rzecz zapewnienia otwartego, powszechnego i trwałego dostępu do polskiego dorobku naukowego i kulturalnego. Artykuł jest umieszczony w kolekcji cyfrowej bazhum.muzhp.pl, gromadzącej zawartość polskich czasopism humanistycznych i społecznych.

Tekst jest udostępniony do wykorzystania w ramach dozwolonego użytku. 
„Zdolność/niezdolność do zawarcia malżeństwa kanonicznego - perspektywa psychologiczna, psychiatryczna i kanonistyczna"

\section{Zdzisław Majchrzyk}

\section{EKSPERTYZY PSYCHOLOGICZNE W KONTEKŚCIE WIZJI OSOBY W UJĘCIU ANTROPOLOGII CHRZEŚCIJAŃSKIEJ}

\section{Wstęp}

Idea rzetelnego poznania prawdy jednostkowej o uczestniku procesowym, stanowi nie tylko rację wyrokowania ale jest również powodem uczestnictwa w procesie biegłego psychologa - jako osoby posiadającej wiedzę specjalną.

Chciałbym z pozycji psychologa zwrócić uwage, na niektóre mim zdaniem ważne czynniki, w których dostrzegam pewien relatywizm w opiniach psychologicznych (podobny także w wyrokach sądowych).

Generalnie można problematykę tę ująć jako asymetrię poznawcza, którą rozumiem jako specyficzne zawężenie interpretacji funkcjonalnej wszelkich odmian patologii, a także normy - bądź eksponowanie zasad teologicznych $\mathrm{w}$ dowodzie prawnym $-\mathrm{z}$ pominięciem uwarunkowań z zakresu psychologii klinicznej, społecznej i kulturowej, etyki, antropologii czy wreszcie filozofii.

Psycholog biegły sądowy i jego dowód, w tym co dotyczy uczestnika procesu sądowego jest pomocny dla sądu. Podlega jednak jego swobodnej ocenie, tak dowód, jak i osoba biegłego - ta świadomość czyni poniekąd biegłego ,zakładnikiem sądu”

\section{Problem czlowieka - tradycja antropologiczna}

Antropologia jako obszar wydzielonych dociekań nad człowiekiem nie pojawia się w pismach filozofów helleńskich. U Arystotelesa czło- 
wiek jako przedmiot rozważań jest przypadkiem. W świadomości jawi się jako „on” a nie ,ja”. „Szczególny wymiar, w którym człowiek poznaje siebie w sposób, w jaki poznać samego siebie może tylko człowiek, pozostaje nietknięty i dlatego nie zostaje odkryte szczególne usytuowanie człowieka w Kosmosie. Dostrzega się jedynie człowieka w świecie, nie dostrzegając zarazem świata w człowieku".

Świat innych filozofów, także Platona i Arystotelesa jest światem optycznym, światem widzialnych kształtów. Jest to świat rzeczy, człowiek jest jedną rzeczą pośród innych rzeczy świata, gatunkiem obok innych, ma określone miejsce w kosmicznym domu.

Psychologia Arystotelesa trzecia wielką koncepcją jaką wydała myśl grecka rozprawia o duszy, „dusza jest forma, czyli energią ciała organicznego"2.

Arystoteles uważał, że przyrodnik ma więcej do czynienia z duszą niż ciałem ${ }^{3}$.

I tak jak Bóg w makrokosmosie, tak dusza w mikrokosmosie jest wyłomem od ogólnej zasady, jaką rządzi się system Arystotelesa, że wszelka forma może istnieć tylko w łączności z materia.

Te założenia filozofii Arystotelesa zaważyły na podstawach psychologii, zwłaszcza psychologii chrześcijańskiej - jeśli takowa istnieje. Moim zdaniem jest jedna psychologia a rożni są uprawiający ją i interpretujący psycholodzy, w tym także chrześcijańscy.

W filozoficznej myśli antropologicznej w ciąu wieków mamy raczej do czynienie z pytaniami antropologicznym niż z nauką, którą można uznać za antropologię sensu stricte. Takie pytania stawiał św. Augustyn. August wyszedł ze szkoły manicheizmu, rozpowszechnionej wówczas gnozy - swoistego rozdarcia bóstwa i zdewaluowania świata. Po latach żyjąc w świecie chrześcijańskim pyta o człowieka: „Kim jest ów człowiek, którego nosisz w pamięci? Pyta kogoś, kto może mu udzielić informacji: qiud ergo sum, Deus meus? Quae natura mea?. Nie tylko samego siebie ma na względzie; słowo natura mówi wyraźnie, że przez osobę rozumie tego człowieka, którego nazywa grande profundum, wielką tajemnicą ${ }^{4}$.

To dziwienie się człowieka samemu sobie, jest czymś zupełnie innym od dziwienia się, które Arystoteles stawia na początku swojego

\footnotetext{
1 M. Buber, Problem człowieka, Warszawa, Wyd. Naukowe 1993, 12.

2 W. Tatrkiewicz, Historia filozofii T.1 Warszawa PWN 1970, 105.

3 Także, s. 105

4 J. Buber, Problem człowieka, Warszawa Wyd.Naukowe 1993 s. 13.
} 
filozofowania. Człowiek Arystotelesowski dziwi się między innymi także człowiekowi, ale tylko jako części zdumiewającego świata. Człowieka augustiańskiego zdumiewa w człowieku to, czego nie sposób zrozumieć jako części świata, jako rzeczy pośród innych rzeczy i dopiero to drugie zdumienie przekształca się w metodyczne filozofowanie, jego własne zdumienie staje się naprawdę głębokie i przejmujące groza. Nie jest ono filozofia, ale wywiera wpływ na przyszła filozofię chrześcijańską̧.

Odtąd wiara buduje nowy kosmiczny dom dla duszy ludzkiej. Chrześcijański kosmos jest rzeczywistością czytelną dla średniowiecznych chrześcijan - Jak maluje to Dante - La divina Commedia. W nim, także czas Biblii nabiera cech chrześcijańskich. Wokół schematu krzyża buduje się obraz świata - jego belka pionowa, skończona przestrzeń, biegnie od nieba do piekieł przez serce osoby ludzkiej, belka zaś poprzeczna, skończony czas, rozciaga się od stworzenia świata do końca dni, przy czym jego środek, śmierć Chrystusa osłaniając i odkupując zajmuje środek przestrzeni, serce biednego grzesznika ${ }^{6}$.

Dla sw.Tomasza nie istnieje szczególny problem istoty ludzkiej. Nie stawia on pytań antropologicznych - w człowieku zadomowionym i nie problematycznym nie ma potrzeby konfrontacji z samym sobą.

Zadania stojące przed antropologią filozoficzną wyraził Kant. Czym jest świat, który poznaje człowiek? Jak człowiek taki, jaki jest w swej konkretnej rzeczywistości, może w ogóle poznawać? Jak czuje się człowiek w poznawanym przez siebie świecie? Czym jest dla niego świat i czym jest on dla świata?

Kant nie projektuje człowiekowi nowego kosmicznego domu, od człowieka jako budowniczego domów żąda się by postanowił poznać samego siebie.

Kant nadchodzące czasy rozumiał jako czasy antropologiczne: czasy godzenia się z sobą i namysłu nad sobą, Ale zadanie odpowiedzi na pytanie czym jest człowiek? miało być podjęte po rozwiązaniu pytań wcześniejszych: Co mogę wiedzieć? Co powinienem czynić? Czego mogę się spodziewać? W części zostało ono spełnione przez przyszłe pokolenia ${ }^{7}$.

$\mathrm{Na}$ interesuje pytanie Co mogę czynić? A to $\mathrm{z}$ tego powodu iż zdaniem Kanta (Krytyka czystego rozumu) jest to pytanie zwrócone do

\footnotetext{
5 Tamże, s. 14

6 Tamże, s. 14

7 Tamże, s. 18
} 
psychologii. Ona powinna odpowiedzieć jak psychicznie realizuje się powinność człowieka.

Allport (1988, s. 9-10) mówiąc niejako o tym spełnieniu wyraża następująco swoją wątpliwość ,każdy kto chce odmalować ducha naszego wieku musi uwzględnić znaczenie psychologii dla współczesnej kultury. Wyciska się ona coraz wyraźniejsze piętno na sposobie myślenia człowieka zachodu. Czy nam się chce czy nie widać to na każdym kroku (...) Tak więc pośród dyscyplin zajmujących się naturą człowieka psychologia jest wprawdzie modna, choć nie wiadomo czy należy się z tego cieszyć". Potwierdza to praktyka kliniczna, co raz trudniej jest, szczególnie starszym psychologom zrozumieć i wyjaśnić rozbieżności zarówno indywidualnego jak i zbiorowego zróżnicowania pojawiających się motywów działania i ich uwarunkowań.

Dopiero w czasach nowożytnych problem antropologiczny został potraktowany jako samodzielny i należycie zgłębiony. Trzy czynniki sprzyjały rozwojowi antropologii.

Pierwszy ma głównie naturę socjologiczną. Ma on związek z rozkładem dawnych wspólnot społecznych i z intensyfikacją międzynarodowych kontaktów i bezpośrednich relacji. Wraz z nowym postępem człowiek podlega alienacji - traci poczucie swego miejsca w świecie, bezpieczeństwo socjologiczne, traci także pewność siebie i spokój, jaki dawały dawne formy oparcia - zwłaszcza rodzina.

Drugi czynnik jest natury psychologicznej. Chodzi tu zwłaszcza o pozycję człowieka względem nowych rzeczy i stosunków powstałych na skutek jego działania lub przy znacznym jego współudziale - (demografia, ekologia). Jedno i drugie wskazują na to, że człowiek jest inaczej zagrożony, nie nadąża za swoim dziełem. Człowiek nie zna sposobu aby unieszkodliwić stworzonego przez siebie Golema.

Trzeci czynnik to życie polityczne - w nim, raczej usytuowany poza nim człowiek coraz częściej uświadamia sobie, że niewiele od niego zależy, raczej staje się igraszką losu, nie ma żadnej mocy aby zapanować nad politycznymi wydarzeniami, a nawet codziennymi sprawami.

Po pierwszej wojnie światowej datuje się szybki rozwój antropologii. Zrozumienie samego siebie - poznanie tajemnicy ludzkiego bycia - zmagania się dobitnie prezentuje m.in. Edmund Husserl.

Postmodernizm wpłynął w zasadniczy sposób na kształtowanie się antropologii. W dyskursie antropologicznym doby postmodernizmu charakterystyczne jest zanegowanie przyjętych zasad w filozofii, nauce i sztuce. 
Antropolodzy doby postmodernistycznej podzielają przekonanie, że współczesny świat kultury jest zbyt złożony, by dawał się ujmować $\mathrm{z}$ jakiejś jednej perspektywie i na jednym planie. $\mathrm{Z}$ tego m.in. powodu uchylają się od wszelkich arbitralnych sądów, monopolizujących ujęć tego świata; tym bardziej że przestał się on już dzielić na centrum i peryferie . $^{8}$.

Celem antropologii jest wsparcie postawy absolutnej tolerancji odmienności. W ramach podejścia relatywizującego nasze sądy o świecie sprowadzają sie do rodzaju „prawd wytworzonych” uwarunkowanych historycznie i kulturowo, bądź językowo. Możliwe są rożne interpretacje od totalnej tolerancji odmienności - po reguły gry językowej - do formy terapeutycznej, wreszcie samo interpretacji jak u Wittgensteina9.

\section{Współczesna psychologia w wyjaśnianiu ludzkiego zachowania}

Wymienię niektóre znaczące teorie.

Zasadnicze wątki psychoanalizy są następujące: działamy realizując nieświadome motywy o charakterze czysto biologicznym. Wszystko co robimy wynika z głęboko ukrytych przed naszą świadomą kontrolą pragnień sprowadzających się do jednego - rozładować popędy, a te są wrodzone i nie wiele różnimy się od naszych mniejszych braci.

Świadome ,ja” człowieka widziane oczami klasycznej psychoanalizy to niewielki obszar ego pozostający całkowicie w służbie dwóch panów: popędów i norm społecznych. Ego freudowskie nie posiada cech autonomicznych. Jego rola sprowadza się do zaspokojenia popędów przy jednoczesnym zachowaniu norm obowiązujących w danej kulturze (Thomson, 1965$)^{10}$.

Człowiek freudowski to osoba $\mathrm{w}$ gruncie rzeczy zniewolona i bardziej skłonna do destrukcji niż do budowania. W tak pojętym funkcjonowaniu człowieka nie ma miejsca na świadomą odpowiedzialność za własne życie. Psychoanaliza zastępuję wolną wolę strażnikiem społecznie wypracowanych zasad - superego i lękiem moralnym, który w tej właśnie strukturze ma swoje źródło.

8 Tamże,s 9

9 K.J. Burszta, K. Piątkowski, O czym opowiada antropologiczna opowieść Warszawa IK.1994.

${ }^{10}$ C. Thomson, Psychoanaliza - narodziny i rozwój. WPN: Warszawa, 1965. 
Odpowiedzialność moralna zakorzeniona przez tradycję chrześcijańską w wolnej woli - w ujęciu psychoanalitycznym znajduje swój odpowiednik w posłuszeństwie wobec nakazów będących wytworem kultury.

Stąd dalsze rozważania na temat uwarunkowań ludzkich destrukcyjnych zachowań sprowadzają się do odpowiedzi na pytania: naturę winić czy kulturę. Przykładem tego myślenia jest głośne opracowanie E. Frooma: Anatomia ludzkiej destrukcyjności (Fromm,1998) ${ }^{11}$.

\section{Behawioralna teoria}

Behawioryzm jest dzieckiem epoki nowożytnej i jej metodologicznych założeń, a tymi przede wszystkim są ograniczenia przedmiotu zainteresowań nauki do faktów (Stachowski, 2000) ${ }^{12}$. Faktem jest to, co może być dostępne obiektywnej obserwacji. Dostępne obiektywnemu doświadczeniu jest tylko zachowanie człowieka. Psychikę człowieka zredukowano do zachowania. Stany psychiczne - myśli i uczucia, jeśli nawet istnieja, mogą być uznane za jedną $\mathrm{z}$ form reakcji nie różniąca się co do swojej istoty od poddającego się obserwacji zachowania.

Jest ono (zachowanie) konsekwencja naszej osobistej historii wzmocnień, czyli kar i nagród, jakie otrzymaliśmy od innych ludzi, losu, od życia. Od nas nie wiele zależy. Nasze zachowanie ukształtowali rodzice, nauczyciele, zewnętrzne okoliczności. Behawioryści nie przypisywali szczególnej roli biologii. Każdy może stać się każdym. Ta myśl - wyrażona w słowach Wathsona „dajcie mi zdrowe niemowlę, a zrobię z niego co chcecie".

W tej perspektywie nie ma miejsca na wolność, odpowiedzialność i godność człowieka. Ludzie są dziełem okoliczności, w które zostali wrzuceni przez los i nie można ich obarczać odpowiedzialnością za to jacy są i jak postępują. Hitler, Stalin, Kuba Rozpruwacz i inni im podobni są ofiarami niesprzyjającej rozwojowi przyzwoitego charakteru historii wzmocnień, podobnie jak zbawcy ludzkości są szczęściarzami, którzy zawdzięczają swój szlachetny charakter warunkom, w których się wychowali. Tych pierwszych nie należy winić, tym drugim - okazywać wdzięczność.

11 Froom E. Anatomia ludzkiej destrukcyjności. Rebis: Poznań. (1998)

12 Stachowski R. Historia psychologii. Od Wundta do czasów najnowszych. w: Psychologia ... red. J.Strelau, 2000, s. 25-66, 84-87. 


\section{Psychologia humanistyczna}

Przekonanie, że człowiek jest wolną istotą zdolną i mająca prawo do twórczego planowania własnej drogi, jest osią psychologii humanistycznej i fundamentalnym rysem koncepcji człowieka. Cel ten widzą oni w stworzeniu warunków wychowawczych, w których nic nie blokuje naturalnej zdolności człowieka do rozwoju bycia szczęśliwą, spełnioną i przyjazną otoczeniu istota.

Wolność, godność i odpowiedzialność to nie jedynie możliwe do osiagnięcia wyżyny człowieczeństwa, ale naturalna kondycja człowieka. Może być ona zahamowana przez wrogie ludzkiej naturze okoliczności, takie jak np. brak troski, miłości i szacunku w okresie najważniejszym dla rozwoju - w dzieciństwie.

Perspektywa humanistyczna daje miejsce odpowiedzialności indywidualnej, chociaż, jak każda szkoła psychologiczna, wskazuje na okoliczności społeczne, które mogą mieć znaczenie w ostatecznym wyjaśnieniu zachowania i przypisaniu winy.

Obok twórczego i odpowiedzialnego podejścia do własnego życia, jednostka ludzka ujęta w kategoriach psychologii humanistycznej jest zdolna do obdarzania uczuciem bliźnich i otaczania ich troską i szacunkiem. Samodzielny, odpowiedzialny, twórczy człowiek psychologów humanistycznych, aby być rozumianym, wymaga indywidualnego podejścia.

\section{Podejście poznawcze}

W początkowym okresie rozwoju psychologii poznawczej metafora człowiek-komputer była popularnym skrótem myślowym oddającym podstawowe wątki podejścia poznawczego. Istota ludzka to przede wszystkim system przetwarzający dane. Chcąc badać psychikę, należy skupić się na tym, jak człowiek odbiera, interpretuje, magazynuje i sam formułuje informacje nieustannie wymieniane ze światem.

Poznawcza aktywność psychiki sprawia, że napływającym danym przypisywany jest sens. Aparat poznawczy aktywnie konstruuje nie tylko wiedzę o świecie, lecz także, co niezwykle ważne, wiedzę o sobie samym. Przewrót kopernikański podejścia poznawczego polega na tym, że od tej pory właściwym pytaniem nie jest to, jaki jest obiektywny stan rzeczy, lecz to, jak ów obiektywny stan rzeczy został odebrany, zinterpretowany, zapamiętany i przypomniany przez umysł ludzki. 
Poznawcza wizja człowieka podkreśla ludzką potrzebę rozumienia świata i siebie, wskazuje na ważny motyw, który kieruje naszym działaniem, a mianowicie na dążenie do nadawania sensu własnemu życiu i lokalizowaniu sensu własnego życia w szerszym porządku rzeczywistości, której jesteśmy elementem. (Berger, Luckman, 2002) ${ }^{13}$.

Poznawcza koncepcja człowieka pozwala na sformułowanie pytań zasadniczych w psychologii i antropologii. Czy granicą ludzkiej wolności jest aparat poznawczy, który buduje wiedzę o świecie, nadaje mu wartości i wyznacza nasze w nim miejsce? Jaka jest nasza możliwości wpływu na to, co mamy w głowie?

\section{Podejście postmodernistyczne}

Nowoczesna koncepcja postmodernistyczna w psychologii jest wynikiem ogólnej refleksji nad funkcjonowaniem człowieka (osoby) w świecie ponowoczesnym, mniej skupia się na wybranych zjawiskach psychicznych (McCrea, Costa, 2005) ${ }^{14}$. Ale osobowość ponowoczesna wymyka się jednoznacznemu określeniu.

Ludzie kameleony to metafora ilustrująca człowieka ery postmodernistycznej. Istotą psychiki staje się zdolność do szybkiej orientacji i gotowość do zmiany - zaczać wszystko od nowa, zmienić repertuar swoich zachowań, preferencji czy postaw, ułożyć życie na nowo $\mathrm{z}$ nowym partnerem. Leży to nie tylko w zakresie możliwości, lecz jest wręcz pożądane i świadczy o zdrowiu psychicznym i kondycji ciała ${ }^{15}$.

Człowiek nowoczesny żyje w nieustannym poczuciu niedoczasu, który oznacza nie tyle brak czasu wolnego, ile brak czasu powolnego (Eriksen, 2001) ${ }^{16}$. Powolność symbolizuje brak odpowiednich predyspozycji do tego, aby być nowoczesnym człowiekiem .

Najlepiej oddają to słowa rosyjskiej biegunki, jednej z wielu barwnych postaci, które pojawiają się w polifonicznej powieści Olgi Tokarczuk Bieguni:

Kiwaj się, ruszaj się, ruszaj. [...] Tylko tak mu umkniesz. Ten, kto rządzi światem, nie ma władzy nad ruchem i nie wie, że nasze ciało

${ }_{13}$ Berger P.L., Luckman T. Społeczne tworzenie rzeczywistości. Warszawa PWN: 1983; J.Trzebiński., Narracyjne konstruowanie rzeczywistości. W: Narracja jako sposób rozumienia świata, red. J.Trzebiński, Wyd. Gdańsk 2002, s. 17-43.

${ }_{14}$ McCrae R.RCosta P.T. Osobowość dorosłego człowieka. Kraków 2005

15 Tamże, s. 3113.

16 Eriksen T.H . Tyranny of the Moment. London. (2001) 
W ruchu jest święte, tylko wtedy mu uciekniesz, kiedy się poruszasz (Tokarczuk 2007) ${ }^{17}$.

Nowocześni bieguni to ludzie w biegu, którzy w odcięciu od przeszłości i przyszłości próbują zagłuszyć samych siebie. Stagnacja, brak zmiany stają się zagrożeniem w świecie, którego jest „za dużo”.

Kulturowo skonstruowany imperatyw „mieć” stał się generatorem ludzkiej aktywności, komunikacji - wreszcie lęku przed byciem z sobą sam na $\operatorname{sam}^{18}$.

Poczucie tożsamości jednostki postmodernistycznej budowane jest na podstawie treści przypominających życiorys, jaki piszemy, starając się o pracę. Pytania jak wieść dobre życie przeformułowane jest na inne: jak osiagnąć sukces. dotrzeć do dóbr powszechnie uważanych za godne pożądania ${ }^{19}$.

Koncepcja postmodernistyczna większą wagę przywiązuje do wyobrażeń przyszłych doświadczeń. Człowiek ponowoczesny jest graczem, który funkcjonuje w świecie zmieniającym reguły w ciagu jednej gry i który w związku z tym ma prawo zmieniać swój system wartości i metody działania, na nowo układać sobie życie, małżeństwo, zmieniać pracę, zawód itp.

Osoba taka to, ktoś o wielu życiorysach, życie jej nie stanowi spójnej narracji, może być zbiorem opowiadań, w których główna postać, choć grana przez tego samego aktora, się nie zmienia. Wszelka stałość i przywiązanie tracą swą racjonalność i ustępują miejsca programowemu nieprzywiązywaniu się do niczego i nikogo.

Psychologowie mówią o tzw. zjawisku pustego ja, czyli osobowości, która nie jest zainteresowana budowaniem stałej tożsamości, definiowaniem siebie jako kogoś o określonych raz na zawsze potrzebach, wartościach dążeniach, posiadającego stałe miejsce w sieci społecznych więzi (Sandel, 1984) ${ }^{20}$.

Cierpienie tych, którzy tracą na zmianie czyichś upodobań, nie jest, a nawet nie powinno być powodem do wyrzutów sumienia. Mając pra-

${ }_{17}$ Tokarczuk O. Bieguni. Kraków,2007 s. 291.

18 Majchrzyk Z.Postmodern individual identity word of collected experiences. Sveikatos Mokslai Health Sciens 2010,2 s.3112-3115.

19 Tamże, s. 3114

${ }^{20}$ Sandel M. The Procedura republic and the unencumbered self. "Political Theory" 1984, nr 12/1 s. 81-96. 
wo autonomicznego wyboru własnej koncepcji szczęśliwego życia, jesteśmy zwolnieni z odpowiedzialności za szczęście innych ${ }^{21}$.

\section{Podejście psychologii pozytywnej}

Zasadniczym założeniem psychologii pozytywnej jest uznanie człowieka za istotę społeczną związaną ze swą grupą i jej tradycją (Seligman, 2005) ${ }^{22}$.

Psychologowie pozytywni rozpoczynają swoją refleksję od konstatacji smutnego zjawiska - szerzącej się epidemii depresji, uczucia smutku, braku spełnienia i utraty poczucia sensu życia wśród przedstawicieli społeczeństwa, któremu obiektywnie rzecz biorąc, niczego nie brakuje i które silnie identyfikuje się z podstawowymi ideami liberalizmu.

Skoro człowiek oderwany od tradycji, od swojej grupy społecznej nie jest szczęśliwy, a sądząc ze wzrostu zachorowań na depresję, nie jest również zdrowy, być może postmodernistyczny styl życia nie odzwierciedla istoty człowieczeństwa, lecz pokazuje jej chorobę, aberrację wynikającą z dobrowolnego przyjęcia roli kolekcjonera przeżyć, turysty, nigdzie nie należącego, wszędzie pojawiającego się tylko przejazdem.

Tożsamości, której istotą jest brak stałości, ciagła gotowość do zmiany; psychologia pozytywna przeciwstawia tożsamość opartą na jedności życia, spójności osoby, jej ról, jej przekonań.

Psychika człowieka funkcjonuje jako narrator, który dba, aby opowieść przez niego pisana posiadała kierunek i sens. Zdrowie i dobrostan psychiczny zależą nie od ilości pozytywnych doznań i pozytywnego bilansu przyjemności i przykrości, jakich w życiu doznajemy, nie od liczby ról, jakie przyszło nam w życiu odegrać, lecz od poczucia sensu naszej egzystencji jako pewnej spójnej całości (McIntyre, 1996) ${ }^{23}$.

Istotą funkcjonowania psychiki jest właśnie budowa narracyjnej jedności życia. W miejsce zatomizowanej tożsamości, człowieka - kameleona, zdolnego do zmiany skóry, gdy tylko pokusa jest wystarczająco duża, psychologia pozytywna stawia osobę szukającą stałości, sensu

21 Tamże, s,3114

22 Seligman M.P.E. Psychologia pozytywna, w: Psychologia pozytywna. Nauka o szczęściu, zdrowiu, sile i cnotach człowieka. Warszawa 2005, s.18-33.

${ }^{23}$ McIntyre A. Dziedzictwo cnoty. PWN:Warszawa 1996, s. 365-402. 
związanego z utrzymaniem jednego kierunku w działaniach i wyborach, jakich dokonujemy.

Narracyjna jedność życia to spójność między wszystkimi rolami, jakie odgrywamy: pracą zawodowa, życiem rodzinnym, między naszą teraźniejszością a czasem, który miną i tym, który dopiero ma nadejść. Spójność przejawia się w przekonaniu o niezmienności swojego ja we wszystkich obszarach życia, a także w stałości swoich przekonań moralnych bez względu na obszar, do którego je odnosimy.

Człowiek w ujęciu psychologii pozytywnej potrzebuje bliskich relacji z innymi ludźmi, aby móc w pełni określić swoją tożsamość. Nie rodzimy się jak czysta karta, rodzimy się w kulturze, w grupie i w tradycji tę grupę określającej. Nie możemy dokonywać wyboru własnej koncepcji szczęśliwego życia z pozycji całkowicie autonomicznej, bez żadnych uprzedzeń, bez odniesień do wartości i sądów podzielanych przez grupę, w której przyszliśmy na świat.

\section{Antropologia chrześcijańska}

Recepcja osiagnięć psychologii i psychiatrii w systemie kanonicznym jest ostrożna i powściagliwa. Nie mniej jednak prawo kościelne opisujące rzeczywistość pomimo swej autonomii jest otwarte na inne dyscypliny. Status biegłych specjalistów określa ich zadania i kompetencje. Podobnie rzecz ma się w problematyce poświęconej niezdolności do zawarcia małżeństwa, prawnicy kościelnie korzystają z osiagnięć psychologii oraz psychiatrii.

Inny, nie mniej ważny problem to umiejętność wykorzystania wiedzy specjalnej. Ten swoisty dialog w oparciu o założenia obu dyscyplin w procesie nieważności małżeństwa jest trudny z kilku powodów. Wyznacza go bowiem wizja antropologii chrześcijańskiej - niezupełnie korelująca $\mathrm{z}$ osiagnięciami psychologii i psychiatrii wreszcie antropologii. W kościele nie funkcjonuje wprawdzie jedna koncepcja antropologii chrześcijańskiej - jedni autorzy skłaniają się ku tezie, iż antropologia winna opierać się na filozofii scholastycznej inni natomiast podkreślają że żaden ze współczesnych modeli filozoficznych nie kwalifikuje się do tego, by stać się bazą dla antropologii chrześcijańskiej ${ }^{24}$.

${ }^{24}$ D. Dzierżon, Niezdolność do zawarcia małzeństwa jako kategoria kanonistyczna, Warszawa 2002, s.111-114 
Pryncypia antropologii chrześcijańskiej są następujące. Przede wszystkim wizja człowieka musi być zgodna z objawieniem. Fundamentem jest, jak to podkreśla Jan Paweł II w swojej encyklice Redemtor hominis zrozumienie człowieka w odniesieniu do Chrystusa i jego dzieła Odkupienia ${ }^{25}$. Osoba ludzka pojmowana jest jako jedność cielesnoduchowa ${ }^{26}$. W ujęciu chrześcijańskim, istota ludzka skażona grzechem pierworodnym doświadcza swojej ograniczoności, ale nie jest pozostawiona samemu sobie, ponieważ człowiek został odkupiony przez Chrystusa i jest wspomagany jego łaską ${ }^{27}$.

Z założeń antropologii chrześcijańskiej wynikają: a) małżeństwo jest instytucją powołaną przez Boga, jest źródłem łaski i uświęcenia; b) zawieranie małżeństwa ujmowane jest w kategoriach odpowiedzi na powołanie Boże; c) w kategoriach personalistycznych jest ujmowane jako wspólnota życia i miłości ${ }^{28}$.

Pojęcia antropologiczne, które często funkcjonują w ekspertyzach psychologicznych, nie nawiązują do określonej teorii , nie oferują integralnej wizji osoby, do rozwiązania przez nie same kwestii znaczenia życia i powołania ludzkiego. Często psychologia przekracza właściwe jej specyficzne kompetencje, wchodząc na obcy teren. Nawet jeśli pewne kierunki badań, dziedziny psychologii i odkrycia, w sferze życia psychicznego (zwłaszcza) podświadomości człowieka uzupełniają lukę w wizji człowieka, to często chodzi o wizję, która nie jest do pogodzenia $\mathrm{z}$ antropologia chrześcijańską.

W sensie ogólnym niezgodne są $\mathrm{z}$ antropologią chrześcijańską są pojęcia zamknięte na wartości i znaczenia, które wychodzą poza dane immanentne i które pozwalają człowiekowi kierować się ku miłości Boga i bliźniego jako swojemu ostatecznemu powołaniu. Pojęcia właściwe licznym kierunkom psychologicznym, zwłaszcza te, które negują możliwość rozumienia innych aspiracji niż te, które narzucone są przez impulsy, uwarunkowania społeczne, lub z idei przesadnie optymistycznej, według której człowiek posiada w sobie takie możliwości,

25 Jan Paweł II, Encyklika Redemtor hominis - 4.03.1979, w: Encykliki ojca św. Jana Pawła II, Kraków 1996, s.7-29

26 Jan Paweł II, Encyklika Veritatis splendor - 6.09.1993, w: Encykliki ojca św. Jana Pawła II Kraków 1996, s.761.

27 Z.Grocholewski, Sędzia kościelny wobec ekspertyz neuropsychiatrycznych i psychologicznych, Prawo Kanoniczne 31(1988) nr 3, s.75-98.

${ }_{28}$ Z.Grocholewski dz. cyt, s.82. 
że własnymi siłami może osiagnąć realizację samego siebie - są odległe antropologii chrześcijańskiej ${ }^{29}$.

Takie, można powiedzieć $\mathrm{w}$ wielkim skrócie są teologiczne odniesienia antropologii chrześcijańskiej. Są one odległe od założeń wielu szkół psychologicznych, takich jak behawioryzm, psychoanaliza psychologia egzystencjalistyczna, psychologia humanistyczna, psychologia poznawcza, a zwłaszcza postmodernistyczna.

Kierunki te $\mathrm{w}$ odniesieniu do małżeństwa trudno pogodzić $\mathrm{z}$ chrześcijańską doktryna, zwłaszcza wówczas, gdy swoiście rozumiana autonomia jednostki redukuje znaczenie jedności małżeńskiej do zwyczajnego środka służącego satysfakcji, samorealizacji, sukcesu czy też egoistycznie pojętej kreacji lub spełnienia wszystkich potrzeb.

Konstruktywne porozumienie pomiędzy biegłym a sędzią kościelnym jest łatwiejsze jeśli dla obydwu punktem wyjścia będzie wspólna antropologia, dzięki czemu mimo odmiennych metod, zainteresowań i celów jedna wizja zostaje otwarta wobec drugiej. Ale niestety jest tak, że współczesna psychologia jest coraz częściej zamknięta na obszary w których porusza się kanonista.

\section{Podsumowanie}

Koncepcje przedstawione powyżej są próbą syntezy, całościowego spojrzenia na człowieka, dokonanej przez psychologów. Zastanowić może cel, któremu służy budowanie takich portretów na gruncie nauki empirycznej świadomej swoich metodologicznych ograniczeń, deklarującej porzucenie wielkich metafizycznych pytań. Intrygujące jest również to, że wizje człowieka przedstawione przez wielkie tradycje filozoficzne różnią się między sobą w zasadniczych kwestiach.

Pytania o wolność, odpowiedzialność moralną, źródła ograniczeń autonomii i ich charakter, zdolność do rozwoju, racjonalność, stosunek do bliźnich - w każdej koncepcji znajdują inną odpowiedź. Budowanie całokształtu portretów człowieka wynika prawdopodobnie z potrzeby zdefiniowania przedmiotu refleksji psychologii, potrzeby, która najwidoczniej jest silniejsza niż podstawy metodologiczne, którym psychologia musi sprostać, aby być zaliczona do grona nauk empirycznych. Różnorodność budowanych koncepcji, szczególnie różnice dotyczące najważniejszych kwestii - wolności i odpowiedzialności wyni-

${ }^{29}$ Z.Grocholewski, Sędzia wobec ekspertyz..., s.80 
kają $\mathrm{z}$ rożnych tradycji filozoficznych, a także $\mathrm{z}$ aktualnego popytu odzwierciedlającego potrzeby i niepokoje doświadczane przez kolejne pokolenia.

Problem wyboru koncepcji, którą sami chcemy stosować, myśląc o człowieku, oceniając jego czyny, próbując go z rozumieć, nie jest kwestią ustalenia kryteriów prawdziwości czy chociażby względnego dopasowania danej koncepcji do rzeczywistości, do tego, jak jest naprawdę.

Portrety przedstawione przez najważniejsze nurty psychologiczne nie są naukowymi teoriami, nie są weryfikowalne i o tym należy pamiętać.

Każda koncepcja chwyta zaledwie pewien element złożonej całości. Można wiec przyjąc strategie czerpania z każdej wizji tego, co aktualnie potrzebne, uznając, że różnorodność obrazów szkicowanych przez psychologów koresponduje $\mathrm{z}$ różnorodnością panującą w rzeczywistości.

Można także zdecydować się na wybór takiego obrazu człowieka, który najlepiej oddaje nasze osobiste intuicje. Ta ostania strategia, choć wydać się może podejrzana ze względu na jawne przyznanie się do opierania się na prywatnych preferencjach jest godna polecenia, szczególnie gdy stosujemy ją z pełna świadomością.

Warto więc zapytać samego siebie, która wizja człowieczeństwa jest nam najbliższa, która wzbudza w nas lęk, a która niesie nadzieje. Konsekwencje uznania jednej z koncepcji za lepiej oddającą istotę człowieczeństwa niż inne ma szczególne znaczenie dla psychologów klinicznych starających się występować w roli biegłego w sprawach o nieważność małżeństwa.

Chodzi o to aby w relacjach biegły - sędzia ten ostatni miał pełną świadomość kompetencji biegłego i nie dał się wprowadzić w błąd z powodu sądów i założeń, nie do przyjęcia przez naukę Kościoła.

Dokonując tego rodzaju wyjaśnień dobrze jest móc umieścić je w szerszym horyzoncie rozważań antropologicznych. Wielkie syntezy, jakimi są antropologiczne koncepcje psychologiczne, dają tylko częściowo taki horyzont. 


\section{Riassunto}

L'autore presenta la recezione delle teorie psicologiche nell'ambito dell'antropologia cristiana. Fornisce un profilo della storia dell'antropologia iniziando da Aristotele, S. Agostino, Kant, Husserl; dall'antropologia postmoderna all'antropologia cristiana. Le basi teoriche della psicologia moderna, per spiegare il comportamento umano, sono illustrate attraverso la presentazione degli assunti di base: la psicoanalisi, il comportamentismo, la psicologia umanistica, la psicologia cognitiva, la psicologia postmoderna, la psicologia comunitaria, sotto l'aspetto dei loro riferimenti al libero arbitrio, all'autocontrollo, al concetto di persona umana. In sintesi, l'autore cerca di dimostrare la possibilità del loro utilizzo da parte di uno psicologo perito, che osserva le nuove norme del Codice di Diritto Canonico del 1983, in particolare i canoni che trattano della validità del matrimonio contratto (can. 1057), e dell'incapacità di contrarre il matrimonio (can. 1057). 